\title{
Stabbing pain in the throat after teeth cleaning
}

\author{
Sara Ersözü, Daniel Hofmänner, Dagmar I Keller
}

Emergency Department, University Hospital Zurich, Zurich, Switzerland

\section{Correspondence to}

Sara Ersözü,

sara.ersoezlue@usz.ch

Accepted 2 August 2017

\section{DESCRIPTION}

A previously healthy, 25-year-old woman presented to the emergency department with mild stabbing pain and foreign body feeling in her throat after cleaning her interdental spaces with a pin, which she accidentally swallowed. Physical examination, including enoral inspection, showed no abnormalities. An anterior-posterior and lateral cervical radiograph was performed (figures 1 and 2).

Radiographically, the pin was identified in the laryngopharynx and therefore laryngoscopy was performed. The pin was found transversely sticking into the epiglottic vallecula. Extraction was possible without anaesthesia using a forceps. No pain, bleeding or infection was reported during the follow-up.

Aspiration of foreign bodies is common in young children and rarely occurs in adults. It is a potentially fatal event due to the risk of asphyxiation. Sharp foreign bodies can, moreover, cause internal injuries and severe bleeding. A few cases of pin aspirations have previously been reported in the literature. ${ }^{1-3}$ They were exclusively found in young Muslim women wearing headscarves. All of them aspirated the pins while holding them between the teeth before securing their veils. Some authors, therefore, suggested a 'Scarf pin-related hijab syndrome'. ${ }^{3}$ Pins were mainly found to be located in the left main bronchus and could be removed by bronchoscopy. ${ }^{13}$ In some cases, even thoracoscopy was necessary. ${ }^{2}$ One patient died due to massive endobronchial bleeding. ${ }^{3}$ Here, we report the first case of pin aspiration while cleaning interdental spaces.

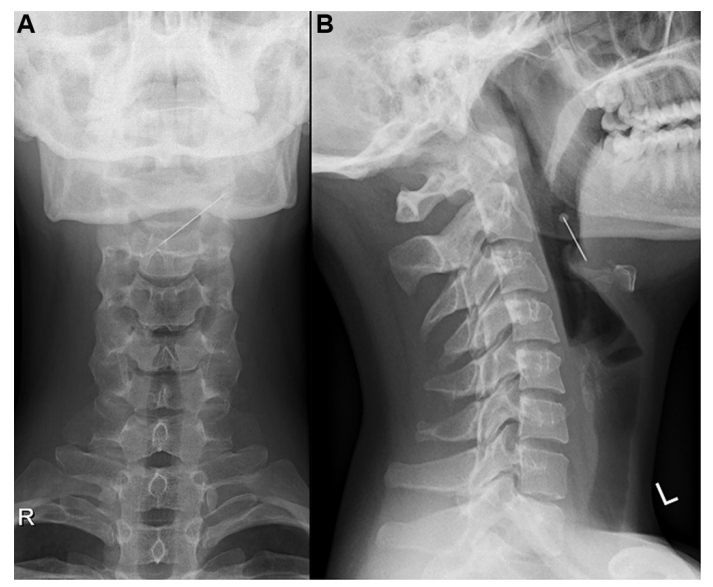

Figure 1 Anterior-posterior (A) and lateral (B)cervical radiographs. $L$, left; $R$, right.

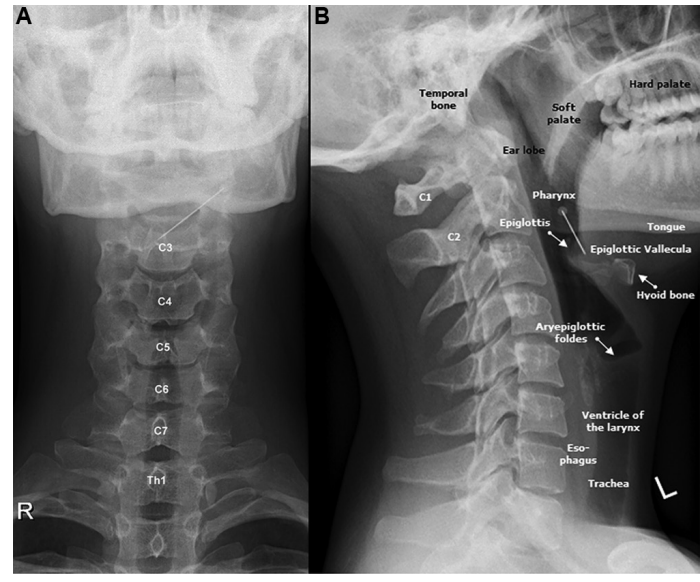

Figure 2 Anterior-posterior (A) and lateral (B) cervical radiographs. A transversely locatedpin is shown at the level of the epiglottis above the hyoid bone. C, cervival vertebra; Th, thoracic vertebra.

\section{Learning points}

- X-ray studies in two planes of the neck, the thorax and abdomen, are indicated to identify the position of metallic foreign bodies in the respiratory and gastrointestinal tract.

- Foreign metallic bodies in the laryngopharynx, such as pins, can be carefully removed using laryngoscopy if the patient is cooperative.

- Physicians should be aware of the rare 'Scarf pin-related hijab syndrome' in young Muslim women and also other circumstances leading to swallowing of pins.

Contributors All authors contributed to patient management in the emergency department. SE drafted the initial manuscript and DH and DIK contributed to writing the manuscript. All authors have provided written consent for publication.

Competing interests None declared.

\section{Patient consent Obtained.}

Provenance and peer review Not commissioned; externally peer reviewed.

(C) BMJ Publishing Group Ltd (unless otherwise stated in the text of the article) 2017. All rights reserved. No commercial use is permitted unless otherwise expressly granted.

\section{REFERENCES}

1 Ilan $\mathrm{O}$, Eliashar $\mathrm{R}$, Hirshoren $\mathrm{N}$, et al. Turban pin aspiration: new fashion, new syndrome. Laryngoscope 2012;122:916-9.

2 Fenane $H$, Bouchikh M, Bouti K, et al. Scarf pin inhalation: clinical characteristics and surgical treatment. J Cardiothorac Surg 2015;10:61.

3 Baram A, Kakamad FH, Bakir DA. Scarf pin-related hijab syndrome: A new name for an unusual type of foreign body aspiration. J Int Med Res 2017. [Epub ahead of print: 1 Jan 2017]. 
Copyright 2017 BMJ Publishing Group. All rights reserved. For permission to reuse any of this content visit http://group.bmj.com/group/rights-licensing/permissions.

BMJ Case Report Fellows may re-use this article for personal use and teaching without any further permission.

Become a Fellow of BMJ Case Reports today and you can:

- Submit as many cases as you like

- Enjoy fast sympathetic peer review and rapid publication of accepted articles

Access all the published articles

- Re-use any of the published material for personal use and teaching without further permission

For information on Institutional Fellowships contact consortiasales@bmjgroup.com

Visit casereports.bmj.com for more articles like this and to become a Fellow 